\title{
Inspiratie voor de nieuwe
}

\section{praktijk}

Voor sommige huisartsen was e-health voorheen een mooie hobby, en voor anderen een 'moetje, maar door COVID-19 zijn we opeens allemaal genoodzaakt om met slimme online opties te komen om goede patiëntenzorg te kunnen blijven leveren. Er is geen tijd meer om de hakken in het zand te zetten, projectplannen te schrijven of te wachten tot de dubbeltjes per patiënt zijn geregeld. Het op poten zetten van nieuwe e-health-toepassingen kostte ooit jaren, maar tegenwoordig schieten ze als paddenstoelen uit de grond. In verandertaal noemen ze dat disruptie. Toch is die verandering misschien niet zo abrupt als het lijkt. Het leven is de laatste jaren in veel opzichten sterk gedigitaliseerd en het is niet meer dan normaal dat we daar met onze zorg op willen ansluiten. Voordat de COVID-19-pandemie in Nederland uitbrak, waren er dan ook al diverse initiatieven op het gebied van e-health: online inzage in het patiëntendossier, consultatie van de huisarts en cognitieve gedragstherapie voor reductie van angstklachten bij adolescenten. Misschien denkt u nu 'Ja, bij adolescenten en jongvolwassenen zal online zorg wel aansluiting vinden, maar hoe zit dat met de grote groep vergrijzende ouderen?' Die zijn over het algemeen verrassend up-to-date, zo blijkt, en niet alleen omdat veel ouderen append en wordfeudend door het leven gaan. Zo laat de HATICE-trial van Eric Moll van Charante et al. over leefstijlcoaching hoopgevende resultaten zien: ook ouderen zijn online goed te begeleiden.

Veel huisartsen vragen zich af: hoe groot wordt het aandeel online zorg in de toekomst eigenlijk? En hoe ziet de praktijkvoering er dan uit in 2030? Dat is koffiedik kijken... Ervaren huisarts Bart Bruijn en waarnemer Isar Wulffaert gaan hierover in discussie en zij verschillen sterk van mening. Lees het dubbelinterview met hen op de website.

De digitalisering van de huisartsenzorg heeft de laatste maanden een grote sprong gemaakt. Laten we die ontwikkeling voortzetten en de vele initiatieven waarover we in dit nummer schrijven (zoals de nieuwe rubriek Best practice) uitbouwen tot volwaardige verbetertrajecten en implementeren in onze zorglijn. Dan heeft COVID-19, naast alle leed, ook iets positiefs opgeleverd. En hoe zit het dan met het NHG-congres over digitalisering van de zorg? Dat beweegt mee met uw digitale verandering en gaat met een digitale kick-off van start op donderdagavond 10 december. De rest zal de toekomst ons leren.

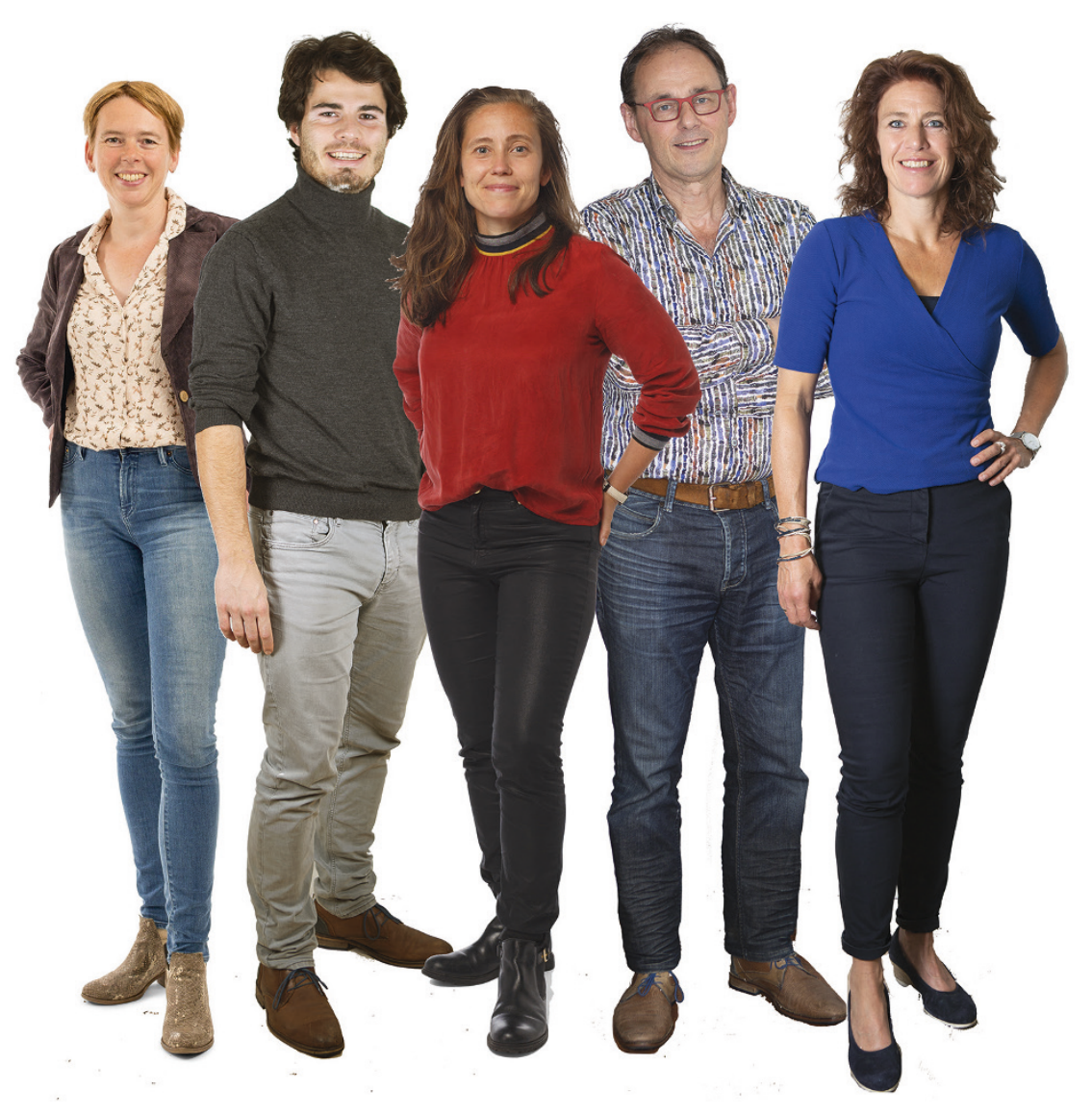

Gastredactie themanummer De nieuwe praktijk (v.l.n.r.): Mirrian Hilbink, Silvan Licher, Kim van Wijck, Bart Timmers, Annet Sollie 